\title{
Art Medium and Art Infrastructure Development in Contemporary Indonesian Art
}

\author{
A. Rikrik Kusmara \\ Fakultas Seni Rupa dan Desain, Institut Teknologi Bandung, \\ Jalan Ganesa No. 10 Bandung 40132, Indonesia \\ Email: rikrik@art.itb.ac.id
}

\begin{abstract}
This research review Indonesian contemporary artists that used the various media in the presentation in his works over the years since 2000 until now. Survey at Pameran Besar Indonesia "Manifesto" in May 2008, were around 670 Indonesian living artists, 350 are consistently professional artists, 41 artists who utilize a variety of media in each works and 6 of them are artists who used a various of media on their solo exhibition including combining conventional media with new media and installation approaches. 6 artists are analyzed on the structure of the media presentation configuration their used, and generally they used more than 3 types of media in their solo exhibition, first, painting/drawing, second, sculpture/object/installation, and third video/photography. In the study of each exhibition process, generally utilizing the curatorial and sponsored by promotor (gallery). This research shows a rapid development of economic infrastructure in Indonesian the art in 2000-an era with the emergence of many auction hall, a new generation of collectors and galleries, and the Asian art market and global orientation, it became one of the holding in contemporary art of Indonesia, has been shifting art situation from cultural appreciation in the era of 90-to an era to cultural production.
\end{abstract}

Keywords: contemporary art; cultural appreciation; cultural production; media arts.

\section{$1 \quad$ Introduction}

Review on art medium in Contemporary Indonesian art based on my previous research about installation art as a discourse and artistic tendency in the 90's; ones of the development of Indonesian art during the two decades since Gerakan Seni Rupa Baru at 75's, with a spirit of 'resistance' in the matter of aesthetic stagnancy discourse in the context of modern Indonesian art and the drift field of socio-political repression during the New Order Regime which cost preventing the development of Indonesian contemporary art. Indonesian Installation art - as an art presentation for many artists, is an act of totality art form: is an effort redefining medium (aesthetic) as well as a part of the artists' active social role.

Received July $5^{\text {th }}, 2010$, Revised October $29^{\text {th }}, 2013$, Accepted for publication November $8^{\text {th }}, 2013$.

Copyright (C) 2013 Published by LPPM ITB, ISSN: 1978-3078, DOI: 10.5614/itbj.vad.2013.4.2.3 
This situation is has been changes drastically after the Reform Era starting in early 2000's. Stereotype of 'tension' in expressing art as a resistance to stagnant regime, that appears on many installation works, slowly been shifted by freedom of choices and fact that the social context change more dynamic and open. This situation then lead to further study about the growing trend of recent contemporary art in Indonesia, asserting the premise that socio political stability has been change toward democratization, economic and prosperity growth and recent cultural discourse, encourage to develop a causality basic assumption between contemporary art discourse as a manifestation of collective problemredefining aesthetic problem and development of the art infrastructure.

\section{Discussion and Analysis}

Contemporary art in the era of the new millennium, marked with the closer 'information distance' from global art world, confirming one of the postmodern identity characteristics, cross discipline convention in art medium toward more flexible creativity characteristics and creates many possibilities in art creation. New media has been proved as a consequence the development of technology and experimental spirit [1], on the other case, representing art medium in the context of traditional medium and new media in sense of simultaneous presentation approach is also more prominent. Art presented through the artist's unique representation; medium discipline becomes a matter of options contextually. Contemporary artists are in a situation the freedom of choices in the media represent ideas through drawing, painting, sculpture, photography, objects and daily life objects (readymades), digital print, video, installation, performance, etc. Indicates medium of art is not merely ideological as purity problems in sense of convention, at the same time issued artistic statements that make it necessary contribution to broadening understanding of the Arts [2].

Flexibility in medium selection for some contemporary artists shows a situation there has been a significant concept-shifting paradigm about medium and problem of representation. Art medium in general not issued merely a control of technique that culminate in the style and artistic typical, say, painter, sculpture or graphic artist as in the modern artistic paradigm. Contemporary artists have a tendency to be more "open" concerning possibility of utilizing a variety of media, and a history of artistic achievement generally was not become linier on one media, but the various approaches to broadening productivity of artwork. Therefore, the term perupa or visual artist most common for some artists.

By reviewing the artists of contemporary Indonesia using various media in the presentation in his works over the years since 2000 until now. From a survey of Visual Arts Exhibition Indonesia "Manifesto" in May 2008, there are about more than 670 Indonesian living artist, about 350 artists professionally active, 
41 artists who utilize a variety of medium in each artistic approaches and 6 of them are artists who use multi medium in many exhibitions and their solo exhibition gathering the traditional medium along with new media and installation. They are: FX Harsono, Tisna Sanjaya, Agus Suwage, Krisna Murti, Ugo Untoro and A. Pramuhendra. Reviewing 6 artists works configurations of the media their used, generally consist of gathering; first, the painting/drawing, second, sculpture/object/installation, and third video/photography (see Figures $1-7)$.

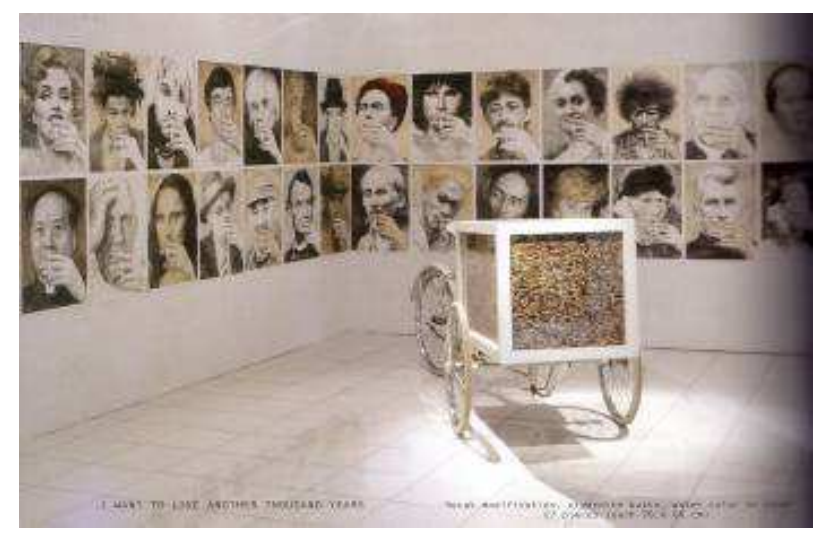

Figure 1 Agus Suwage 2007, I want to live another thousand years, Becak Modification, Cigarette Butts, Water Color on Paper $75 \times 75$. Solo Exhibition I/CON Nadi Gallery 2007.
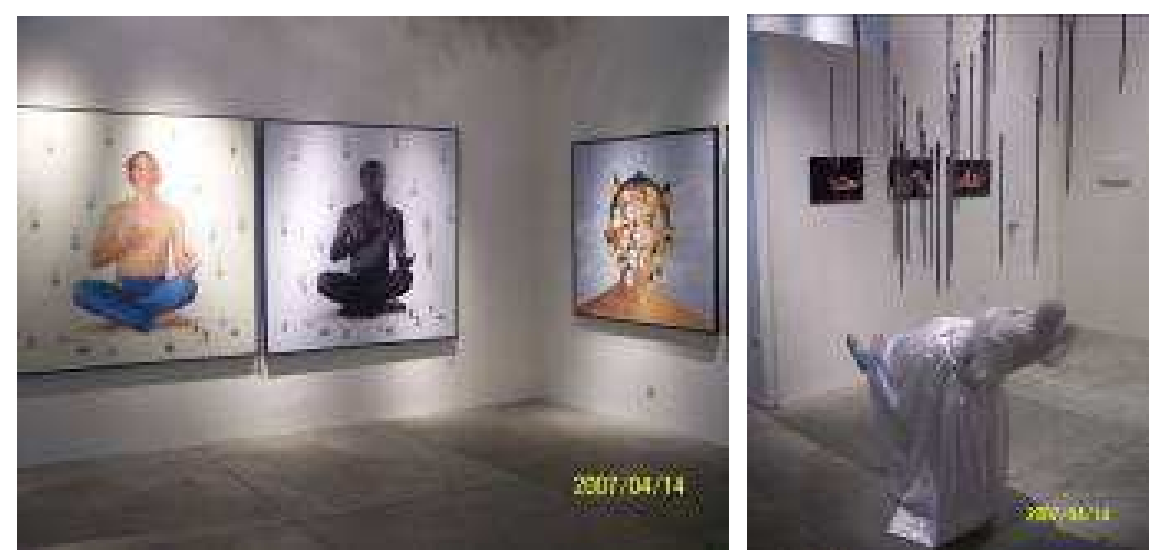

Figure 2 Solo Exhibition “Titik Nyeri”, Instalasi, Digital Fotoprint, Digital Print. Acrilyc on Canvas Langgeng ICON Jakarta, 2007. 


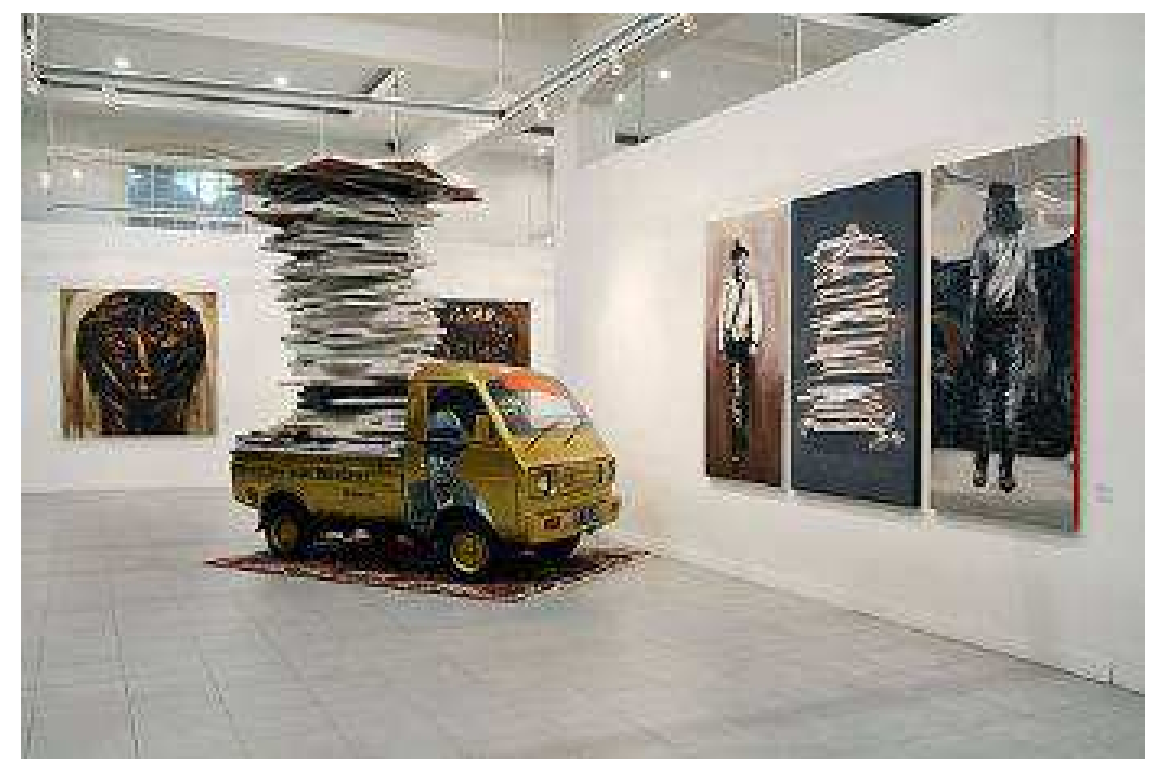

Figure 3 Solo Exhibition Tisna Sanjaya, Ideocracy, Installation, Painting, Video National Gallery Jakarta 2008, source: Universe-Universe.org.

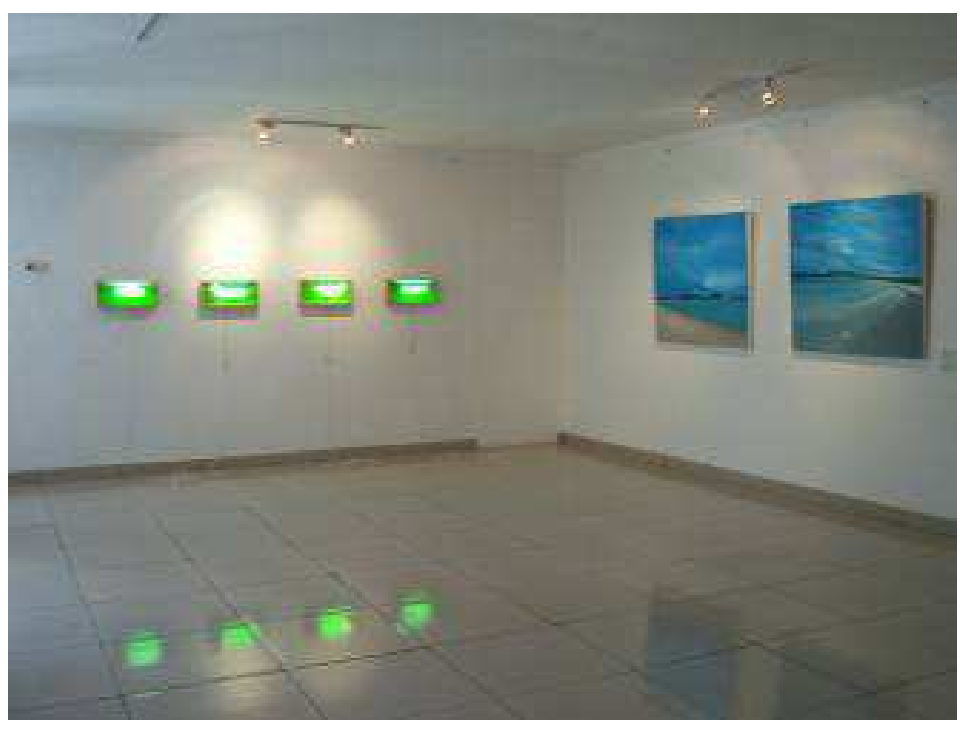

Figure 4 Solo Exhibition "Forbidden Zone" 2008, Rumah Seni Yaitu, Semarang (14-29 March 2008); Gaya Fusion of Senses, Ubud (5-23 April 2008); National Gallery Jakarta (29 April-11 May 2008). 


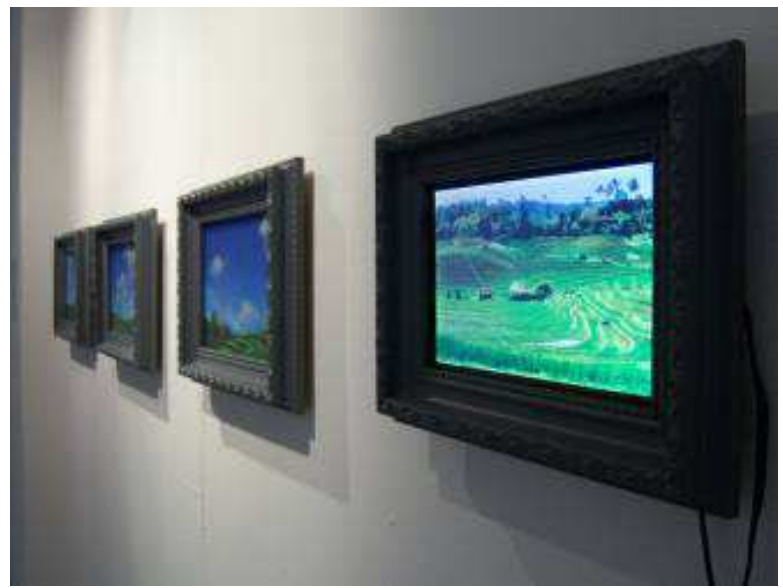

Figure 5 Solo Exhibition "Forbidden Zone" 2008, Rumah Seni Yaitu, Semarang (14-29 March 2008); Gaya Fusion of Senses, Ubud (5-23 April 2008); National Gallery Jakarta (29 April-11 May 2008).

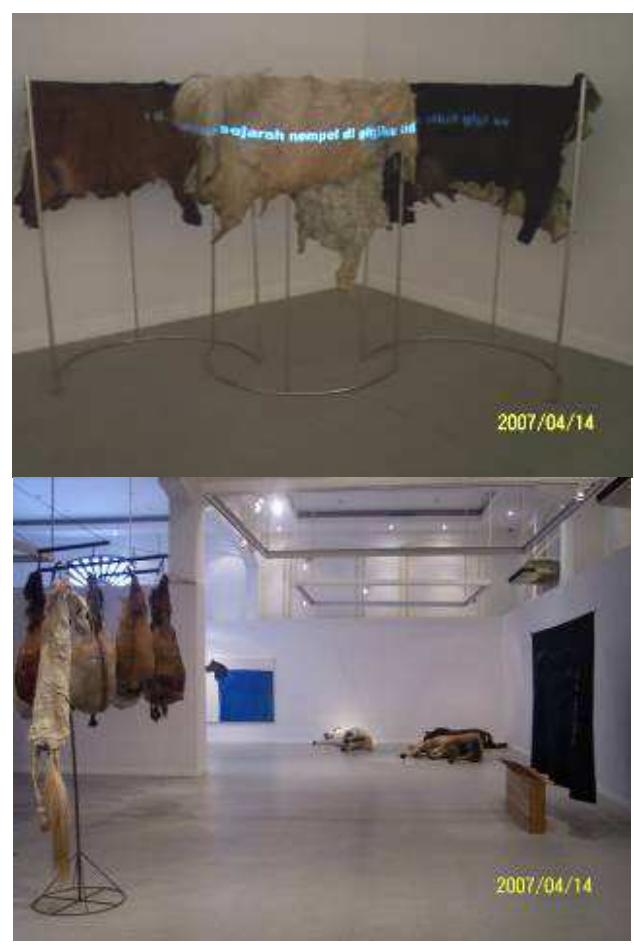

Figure 6 Solo Exhibition "Poem of Blood. Ugo Untoro, Painting, Installation, mix media. National Gallery Jakarta 2007. 


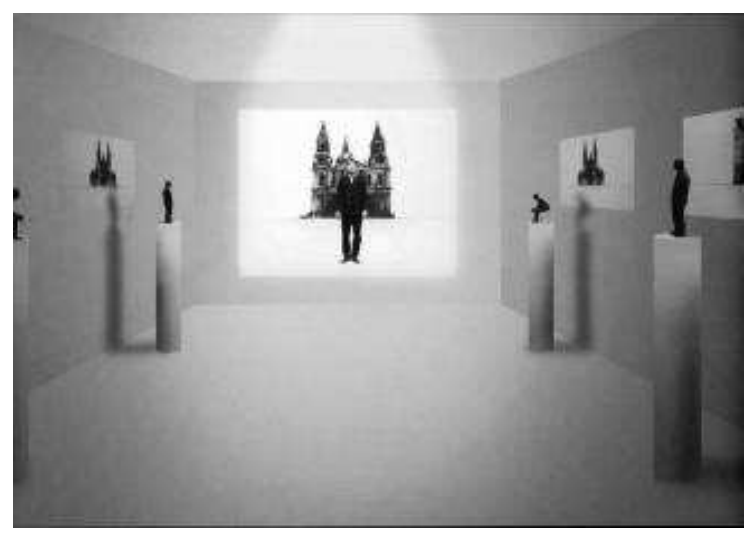

Figure 7 Ariadhitya Pramuhendra, 2008 lost in journey, fiberglass object, charcoal drawing on paper, drawing video animation, variable dimension, Bandung New Emergence II . Selasar Soenaryo Art Space.

\section{$3 \quad$ Results}

In all exhibition process, most of the exhibition curated and supported or promoted by private gallery. At this stage, found a strong relationship among of art medium, artist, curator and promoter, the four components that formed in relationship to accommodate problem representation of art as cultural capital and economic capital mechanism, this tendency direct a causality factors of representation through art medium and the mechanism of appreciation or collection.

Since the early 2000's until recently, activity of exhibition drastically raised more than doubled, however, supporting infrastructure such as art galleries, the collection mechanism and media information of art is generally supported by the private sector, even the National Museum and National Gallery also rely on the cooperation with many private gallery in many activities, the development of Indonesian contemporary art is not significantly support by state government. In doctoral thesis on Alternative Art in Indonesia, Susan Helen assert, If we place the Indian art world against an ideal Western template, there are superficial similarities but closer examination indicates the absence of any workable public institutions supporting a contemporary art culture or the development of a modern art historical consciousness. Major Art Exhibitions are often improvised and dependent on private sponsorship or support that can be unpredictable [3].

It is therefore not surprising if one of the growth variable of contemporary art are based on economic market mechanisms, will end in the auction hall which is 
also growing rapidly in Indonesia recently, and the increased of private galleries participation displays the works of contemporary Indonesia art in the international art fair, such as in Beijing, Singapore, Hong Kong, Taipei, Shanghai.

This issue, which was then one of the sample paradigms of contemporary art representation of artists mentioned above. Configuring media painting/drawing, along the media sculpture/object/installation, and third media video/ photography is one mechanism presentation was influenced by complex network integration between cultural capital (concerning art and artists) and the market packed by the art curator, promoter (Gallery). Establishment of painting/drawing which have a long fine art tradition, combined with the principle of totality in the work of Installation or three dimensions art object, as well as video and photography as an approach to spirit new media, gathered into exhibition presentation mechanisms package for strengthening each other and to gain blend of economic capital and cultural capital, instead of being tends to side on merely the economy or simply the idealization art of representation that require adequate financial support. Therefore, the fact is, although the collection of Indonesian contemporary art began to move on the development of new media art, but works of painting, in general, remain one of the main buffer area of Indonesian contemporary art development.

\section{Conclusion}

This practice generally is not applicable to all artists in Indonesian contemporary art, but the case was give enough description most of the contemporary art infrastructure are driven by the Indonesian private sector, it raise awareness of the mechanism of art presentation package as a branding construction and art production system which become a narrowed system artistic fields function and the implications their processes have for art and artistic practice or art rules in Pierre Bourdieu accounts [4]. In the era of 90's contemporary art in Indonesia, which appear most in alternative gallery like Cemeti at Jogjakarta and International Biennial and Triennial are cases mechanism of exhibition supported by foreign non-profit institutions, emphasize aspects of the successful cultural appreciation. Meanwhile, in this case study, contemporary art in Indonesia is now a led to mechanism of the cultural production, an art presentation forms as close bind to economic system.

\section{References}

[1] Rush, M. 2005. New Media in Art, Thames and Hudson World of Art, pp. 7. 
[2] Davies, D. 2003. Medium in Art, The Oxford Handbook of Aesthetics, Oxford Univ. Press, pp. 190.

[3] Ingham, S.H. August 2007. Alternative Art and Infrastructure in Indonesia in the 1990s, School of Art History and Theory College of Fine Arts University of New South Wales, pp. 69.

[4] Grenfell, M. \& Hardy, C. 2007. Art Rules, Pierre Bourdieu \& the Visual Art, Berg Publisher. 